\title{
Investigation of the Effect of Anodizing Dyes Using Purple Cabbage and Dragon Fruit Peel on Aluminum 6061alloy
}

\author{
Pungky Eka Setyawan ${ }^{1 *}$ Elta Sonalitha $^{2}$ Didit Abryanto Asmono $^{3}$ Rifki Akbar Refitra ${ }^{3}$ \\ ${ }^{1,3}$ Department of Mechanical Engineering \\ ${ }^{2}$ Department of Electrical Engineering \\ Faculty of Engineering, University of Merdeka Malang \\ Malang, Indonesia
}

\begin{abstract}
Anodizing on aluminum 6061 was carried out to improve the mechanical properties and aesthetic value of the specimen surface. Anodizing produces a thin, porous oxide layer resulting in hard surface properties and corrosion resistance. The pores resulting from the anodizing process can be used to provide various colors when filled with dyes. Coloring in the anodizing process can be done with chemical dyes or natural dyes. Anodizing using chemical solutions produces waste that can be harmful to the environment. To overcome this pollution problem, a natural dye solution is used using dyes from purple cabbage and dragon fruit peel so that it is expected to minimize the impact of environmental pollution. The purpose of this study was to investigate the effect of using natural dyes produced from purple cabbage and dragon fruit peel on anodizing aluminum 6061. The investigation is carried out through visual color testing, coating thickness testing, micro-structure testing, and micro Vickers hardness testing. From these results, it was found that the variation in the concentration of the dye solution did not affect the thickness of the resulting oxide layer. The oxide layer and pore size are influenced by temperature, electric current, voltage, solution concentration, and immersion time in the electrolyte solution during the anodizing process. So the factors that greatly influence the diffusion quality of the dye solution are the correct pore size and thickness of the oxide layer so that the dye can adhere perfectly to the surface of the specimen.
\end{abstract}

Key Words: Aluminum alloy, Anodizing, Fruit Waste, Vegetable Waste, Staining.

\section{INTRODUCTION}

In general, the properties of aluminum include: having a relatively lightweight with a specific gravity of $2.7 \mathrm{~g} / \mathrm{cm}^{3}$ or about $1 / 3$ of the density of steel $\left(7.86 \mathrm{~g} / \mathrm{cm}^{3}\right)$. The tensile strength of pure aluminum is $90 \mathrm{Mpa}$, and its physical properties can be improved by adding alloying elements [1]. When combined with the elements, the tensile strength ranges up to $600 \mathrm{MPa}$. The advantages of Aluminum are that it is easy to bend, machine-treat, cast, draw and extrude. Aluminum 6061 is generally applied to automotive and construction tools because it has fairly good machinability, corrosion, thermal and electrical conductivity. Magnesium and Silicon form the compound Mg2Si (Magnesium Silicide) which gives high strength to aluminum alloy 6061 [2].

Anodizing is a simple electrochemical process that was developed in the 20th century by forming a protective layer of aluminum oxide on the aluminum surface. This process produces a thin porous oxide layer that is hard and corrosion-resistant. The porous layer can be used to provide various colors when filled with dyes [3]. The anodizing process can be done with chemical dyes. One method that can be used to improve physical properties includes changes in color brightness and color coating thickness on aluminum after the coloring process in the anodizing process [4], [5].

Previous research, an anodizing process using ingredients from tea leaves as coloring had been conducted [4]. The resulting color depends on the immersion time and the concentration of the tea solution used. The anodizing result using black tea dye produces a golden yellow to brownish-yellow color. If the concentration of the dye used is higher, it will produce a darker color [6].

An aluminum coloring also had been conducted by previous researcher by an anodizing process using dye from fragrant of pandan wangi leaves [7]. The color produced from fragrant pandan wangi leaves is green. The color produced from the anodizing process depends on the length of time immersing and the concentration of pandan wangi leaf solution used. According to this research, it was found that if the concentration of the dye solution used was higher, the brighter the resulting color would be [8]. 
Another study used extraction from mangosteen peel as a natural dye in the anodizing process [9]. The color produced from the mangosteen peel extraction ranges from light yellow to brownish-yellow. The higher the color concentration, the darker the color will be. Turmeric also was used as a natural dye in the anodizing process. This research produces colors that are not yet uniform and different. According to some of the research results above, it shows that the concentration of the dye solution used in the dyeing process greatly affects the results of the color brightness [6].

According to the several previous studies, purple cabbage and dragon fruit peel were used as alternatives to natural dyes for anodizing aluminum 6061. This study was conducted to determine the mechanical properties of the effect of dyeing on anodized aluminum 6061 using natural dyes from purple cabbage and dragon fruit peel through testing. visual color, coating thickness testing, microstructure testing, and micro Vickers hardness testing.

\section{METHODOLOGY}

The method used in this research is the laboratory experimental method. The research was carried out in several stages, namely preparation, anodizing process, the coloring process using vegetable waste, namely purple cabbage and fruit waste from dragon fruit peel, then tested on the research specimen. The material used in this research is aluminum alloy 6061 with dimensions of 10 $\mathrm{mm} \times 33 \mathrm{~mm}$ x $22 \mathrm{~mm}$. The research flow diagram can be shown in Figure 2.1.

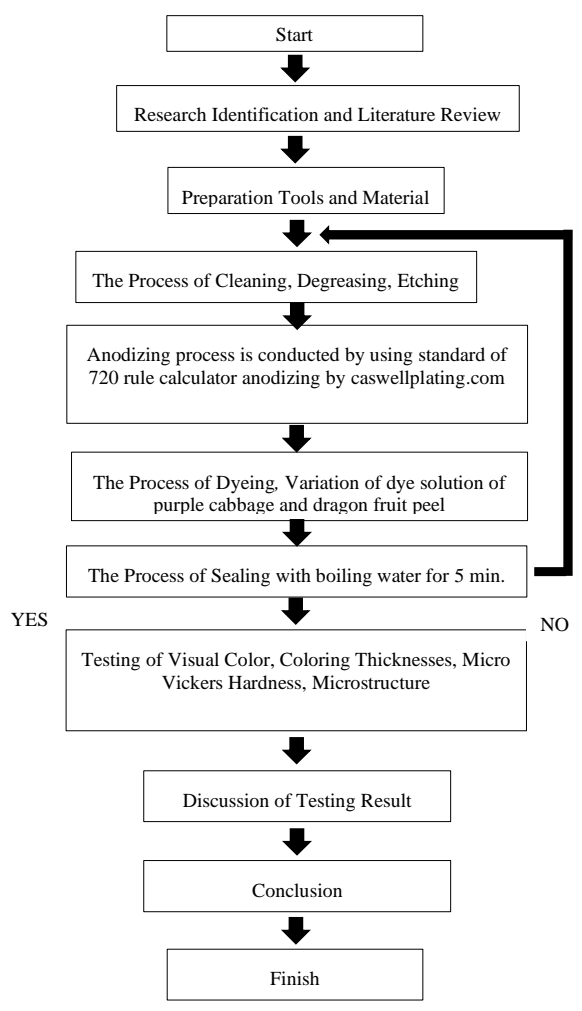

Figure 2.1: Research Flowchart

This research was conducted using several independent variables such as variations in the types of dyes, namely purple cabbage and dragon fruit peel mixed with nitric acid and aquadest then processed by distillation and food coloring with different compositions. For current, voltage, and anodizing time follow the standard 720 rule calculator anodizing by caswellplating.com. Table 2.1 below shows the specimen numbering and the type of treatment performed.

Table 2.1 Number of Specimens and Type of Treatment

\begin{tabular}{|c|c|c|}
\hline No & $\begin{array}{c}\text { Specimen } \\
\text { Code }\end{array}$ & Treatment \\
\hline 1 & $2 \mathrm{u}$ & $\begin{array}{c}15 \mathrm{ml} \text { purple food coloring, 120 ml purple cabbage distillate, } \\
865 \mathrm{ml} \text { aquadest (1000 ml dye solution) }\end{array}$ \\
\hline 2 & $3 \mathrm{u}$ & $\begin{array}{l}30 \mathrm{ml} \text { purple food coloring, 120 ml purple cabbage distillate, } \\
850 \mathrm{ml} \text { aquadest (1000 ml dye solution) }\end{array}$ \\
\hline 3 & $5 \mathrm{u}$ & $45 \mathrm{ml}$ purple food coloring, 120 ml purple cabbage distillate, \\
\hline
\end{tabular}


International Journal of Advances in Scientific Research and Engineering (ijasre), Vol 7 (2), February -2021

\begin{tabular}{|c|c|c|}
\hline & & $835 \mathrm{ml}$ aquadest (1000 $\mathrm{ml}$ dye solution) \\
\hline 4 & $6 u$ & $\begin{array}{l}15 \mathrm{ml} \text { purple food coloring, } 150 \mathrm{ml} \text { purple cabbage distillate, } \\
835 \mathrm{ml} \text { aquadest ( } 1000 \mathrm{ml} \text { dye solution) }\end{array}$ \\
\hline 5 & $7 \mathrm{u}$ & $\begin{array}{l}30 \mathrm{ml} \text { purple food coloring, } 150 \mathrm{ml} \text { purple cabbage distillate, } \\
820 \mathrm{ml} \text { aquadest ( } 1000 \mathrm{ml} \text { dye solution) }\end{array}$ \\
\hline 6 & $8 \mathrm{u}$ & $\begin{array}{l}45 \mathrm{ml} \text { purple food coloring, } 150 \mathrm{ml} \text { purple cabbage distillate, } \\
805 \mathrm{ml} \text { aquadest ( } 1000 \mathrm{ml} \text { dye solution) }\end{array}$ \\
\hline 7 & 3 & $\begin{array}{l}15 \mathrm{ml} \text { red food coloring, } 120 \mathrm{ml} \text { dragon fruit peel distillate, } \\
865 \mathrm{ml} \text { aquadest ( } 1000 \mathrm{ml} \text { dye solution) }\end{array}$ \\
\hline 8 & 5 & $\begin{array}{l}45 \mathrm{ml} \text { purple food coloring, } 120 \mathrm{ml} \text { dragon fruit peel } \\
\text { distillate, } 835 \mathrm{ml} \text { aquadest ( } 1000 \mathrm{ml} \text { dye solution) }\end{array}$ \\
\hline 9 & 6 & $\begin{array}{l}15 \mathrm{ml} \text { purple food coloring, } 150 \mathrm{ml} \text { dragon fruit peel } \\
\text { distillate, } 835 \mathrm{ml} \text { aquadest ( } 1000 \mathrm{ml} \text { dye solution) }\end{array}$ \\
\hline 10 & 7 & $\begin{array}{l}30 \mathrm{ml} \text { purple food coloring, } 150 \mathrm{ml} \text { dragon fruit peel } \\
\text { distillate, } 820 \mathrm{ml} \text { aquadest ( } 1000 \mathrm{ml} \text { dye solution) }\end{array}$ \\
\hline 11 & 8 & $\begin{array}{l}45 \mathrm{ml} \text { purple food coloring, } 150 \mathrm{ml} \text { dragon fruit peel } \\
\text { distillate, } 805 \mathrm{ml} \text { aquadest ( } 1000 \mathrm{ml} \text { dye solution) }\end{array}$ \\
\hline 12 & 9 & $\begin{array}{l}45 \mathrm{ml} \text { purple food coloring, } 120 \mathrm{ml} \text { dragon fruit peel distillate } \\
835 \mathrm{ml} \text { aquadest ( } 1000 \mathrm{ml} \text { dye solution) }\end{array}$ \\
\hline
\end{tabular}

\subsection{Steps of Anodizing Process}

The steps of the anodizing process of 6061 aluminum specimens with purple cabbage dye and dragon fruit peel include:

\section{a. Degreasing}

Degreasing is the process of cleaning the workpiece from dirt and oil attached to the specimen before etching. The solution used in the degreasing process is sulfuric acid $\left(\mathrm{H}_{2} \mathrm{SO}_{4}\right)$. After that, rinsing cleaning is carried out, namely the process of rinsing the workpiece from chemicals that stick to the aluminum surface after the cleaning process using distilled water [10].

\section{b. Etching}

The etching is the process of chemically removing the oxide layer on the aluminum surface that cannot be removed from the cleaning process and aims to obtain a flatter and smoother workpiece surface. This process uses lye $(\mathrm{NaOH})$. After that, rinsing etching is carried out, namely the process of rinsing the workpiece after the etching process using distilled water [11].

\section{c. Anodizing}

Anodizing is often called anodic oxidation, which is the process of forming an oxide layer $\left(\mathrm{Al}_{2} \mathrm{O}_{3}\right)$. The workpiece is attached to the anode (+) and the tin sheet $(\mathrm{Pb})$ is attached to the cathode (-). The solution used in this process is sulfuric acid $\left(\mathrm{H}_{2} \mathrm{SO}_{4}\right)$. Next is rinsing anodizing, namely the process of rinsing the workpiece after the anodizing process using distilled water[12].

\section{d. Dyeing/Coloring}

Dyeing is the process of coloring the pores of the oxide layer which is formed after the anodizing process so that it will produce an attractive color on the aluminum surface. The dyes used are purple cabbage and dragon fruit peel mixed with aquadest, nitric acid, and food coloring [13].

\section{e. Sealing}

Sealing functions to close the pores of the oxide layer resulting from the anodizing process which is still open. Sealing also prevents the dye from escaping from the pores of the oxide layer, making it difficult for colors to fade. After the sealing process, the layer structure will be smooth and even. This process uses a solution of acetic acid or vinegar $\left(\mathrm{CH}_{3} \mathrm{COOH}\right)$ [14]. 
International Journal of Advances in Scientific Research and Engineering (ijasre), Vol 7 (2), February -2021

\section{f. Rinsing Sealing}

The rinsing sealing process is the process of cleaning the aluminum workpiece after the sealing process using distilled water from chemicals that stick to the aluminum surface, thus no chemical residue sticks to the aluminum surface [14].

\subsection{Specimen Testing}

Testing of the material resulting from anodizing staining with purple cabbage and dragon fruit peel includes 4 types of tests, namely as follows:

\section{a. Color Visual Testing}

Color visual testing through image analysis involves a lot of visual perception. This process has input data and output data in the form of images. Digital images can be obtained automatically from a digital image capture system that performs image browsing and forms a matrix, where the matrix elements represent the value of light intensity at a discrete set of image points. Calculation of the color index parameters R, G, and B is obtained from each pixel in the image. Generating characteristics from images can also be based on the color index value of RGB (Red, Green, Blue) using color analysis software.

\section{b. Coloring Thickness Testing}

This test is a data collection of the thickness of the oxide layer that is formed on the surface of aluminum 6061 using a Thickness Gun. Where the thickness value is taken at 3 surface points then averaged.

\section{c. Micro Structure Testing}

Microstructure testing was carried out on the surface of the specimens stained with purple cabbage and anodized dragon fruit peel using a Nikon optical microscope with a 200x magnification.

\section{d. Hardness Testing}

Hardness testing was carried out on the surface of the stained specimens with purple cabbage and anodized dragon fruit peel using the Vickers micro-test. The micro Vickers test was chosen because this test is compatible with testing the hardness of small or complex areas.

\section{RESULT AND DISCUSSION}

\subsection{Color Visual Test Results}

Following are the results of testing color brightness with color brightness (RGB) using color analysis software.

Table 3.1 Visual anodizing test results with purple cabbage dye

\begin{tabular}{|c|l|c|c|c|c|c|}
\hline No & Specimen & Red & Green & Blue & Percent & Colour group \\
\hline 1 & Specimen $2 \mathrm{u}$ & 73 & 74 & 92 & 60.59003 & Cyan-Blue \\
\hline 2 & $\begin{array}{c}\text { Specimen } 3 \mathrm{u} \\
3\end{array}$ & 41 & 28 & 48 & 64.49565 & Green-Cyan \\
\hline 4 & $\begin{array}{l}\text { Specimen } 5 \mathrm{u} \\
-\end{array}$ & 63 & 43 & 68 & 68.82746 & Cyan-Blue \\
\hline 5 & $\begin{array}{l}\text { Specimen } 6 \mathrm{u} \\
6\end{array}$ & 73 & 74 & 95 & 53.08397 & Cyan-Blue \\
\hline 6 & Specimen $8 \mathrm{u}$ & 74 & 56 & 78 & 38.18713 & Cyan-Blue \\
\hline & 0 & 68 & 55 & 72 & 59.63992 & Cyan-Blue \\
\hline
\end{tabular}




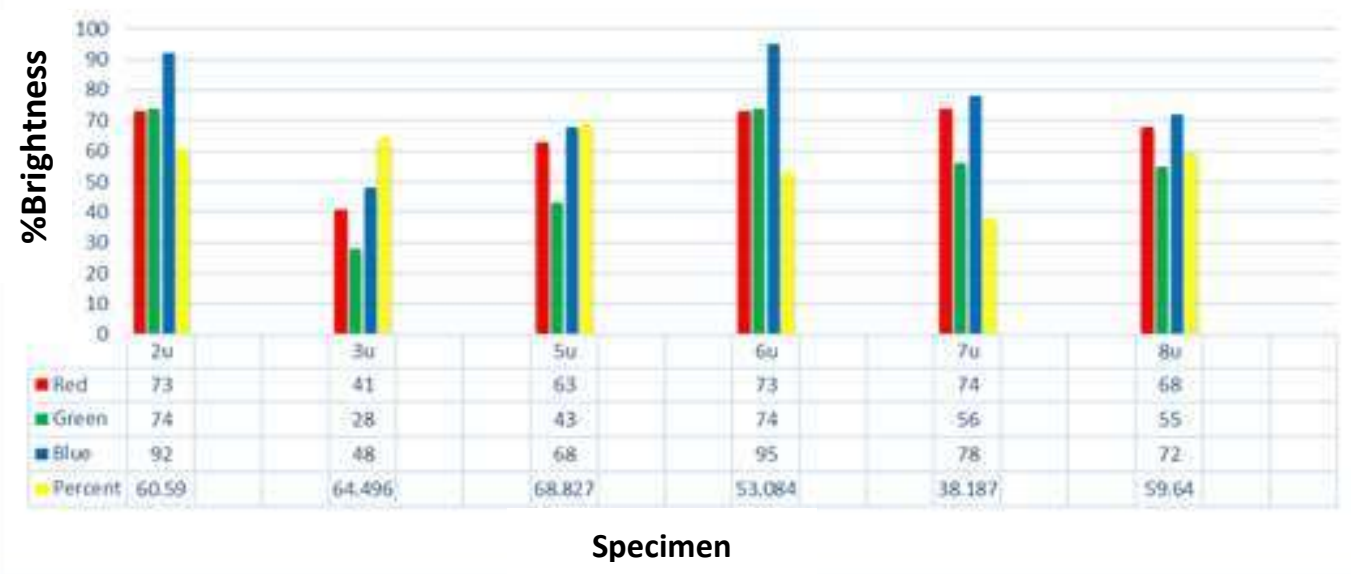

Figure 3.1 Graph of Visual Testing Results Color Anodizing Process Using Purple Cabbage Dye

Figure 3.1.Shows the results of color brightness (RGB) in the anodizing process using purple cabbage dye specimens $2 \mathrm{u}$ R $73 \%$, G 74\%, B 92\%, 3u R 41\%, G 28\%, B 48\% specimens, 5u R 63\% specimens, G 43\%, B 68\%, specimen 6u R 73\%, G 74\%, B 95\%, specimen 7u R 74\%, G 56\%, B 78\%, specimen 8u R 68\%, G 55\%, B 72\% The graph explains that the dominant color composition is Blue due to the pores of the oxide layer which are filled with a dye solution based on purple cabbage used in this study. Then, for the highest brightness in the $6 \mathrm{u}$ specimen with $53.08397 \%$ (table 3.1), the color is dominated by cyan-blue with $\mathrm{R} 73 \%$, $\mathrm{G}$ $74 \%$, B 95\%, and indeed the resulting color is better and evenly distributed compared to other specimens. Thus, a composition of $15 \mathrm{ml}$ of purple food coloring, $150 \mathrm{ml}$ of purple cabbage distillate, $835 \mathrm{ml}$ of aquadest ( $1000 \mathrm{ml}$ of dye solution) produces the best color. It is thought that there is a residue from the composition of the purple cabbage solution which diffuses on the aluminum surface. This is proven empirically. The resulting lighter color on aluminum is due to differences in the composition of the solution mixture.

Table 3.2 Visual Anodizing Test Results with Dragon Fruit peel Coloring

\begin{tabular}{|c|c|c|c|c|c|c|}
\hline No & Specimen & Red & Green & Blue & Percent & Colour group \\
\hline 1 & Specimen 3 & 97 & 65 & 68 & 24.76971 & Magenta-Pink \\
\hline 2 & Specimen 5 & 114 & 68 & 68 & 43.02376 & Red-Orange \\
\hline 3 & Specimen 6 & 156 & 92 & 119 & 27.73526 & Red-Orange \\
\hline 4 & Specimen 7 & 81 & 40 & 56 & 20.15753 & Orange And Brown \\
\hline 5 & Specimen 8 & 92 & 53 & 58 & 17.75888 & Orange And Brown \\
\hline 6 & Specimen 9 & 91 & 109 & 168 & 51.70290 & Dark Pastel Blue \\
\hline
\end{tabular}




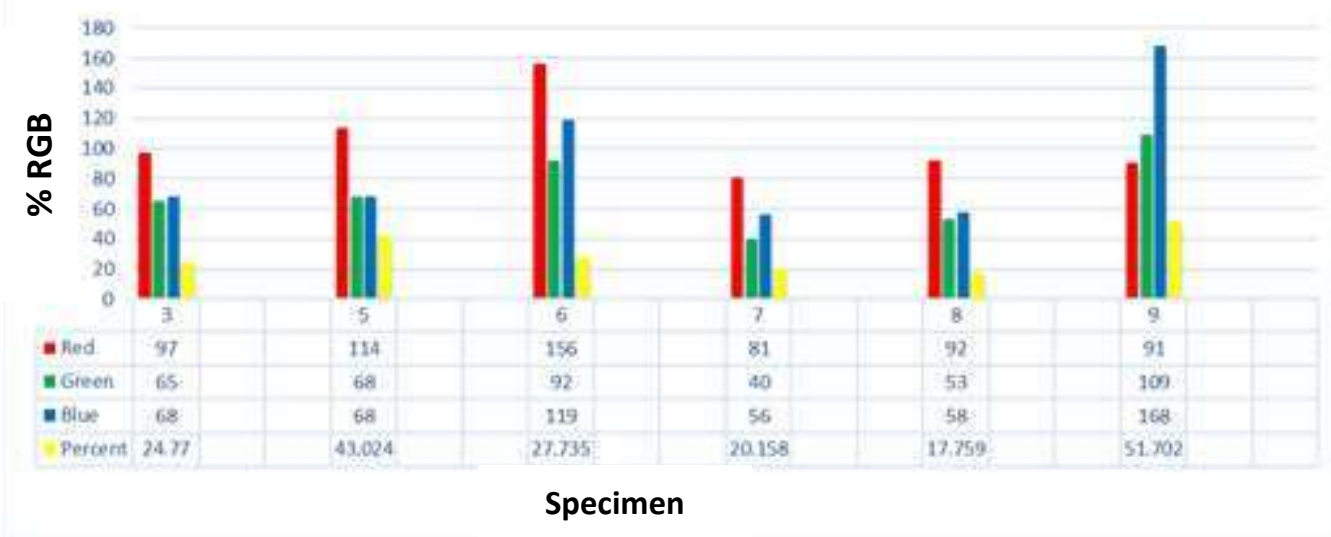

Figure 3.2. Graph of Visual Testing Results Color Anodizing Process Using Dragon Fruit peel Dyes

Figure 3.2.shows the results of color brightness (RGB) in the anodizing process using dragon fruit peel dye. Specimen $3 \mathrm{R} 97 \%$, G $65 \%$, B 68\%, 5 R 11\%, G 68\%, B 43\% specimen, 6 R specimen 156\%, G 92\%, B 119\%, specimen 7 R $81 \%$, G 40\%, B 56\%, specimen 8 R 92\%, G 53\%, B 58\%, specimen 9 R 91\%, G 109\%, B 168\% The graph explains that the dominant color composition is Red due to the pores of the oxide layer which are filled with a dye solution made from dragon fruit peel as the base ingre dient of this research. Then, for the highest brightness in specimen 6 with $27.7353 \%$ (table 3.2), it is dominated by Red - Orange color with R 156\%, G 92\%, B 119\%, and indeed the resulting color is more by the dragon fruit peel color compared to another specimen. So with a composition of $15 \mathrm{ml}$ of red food coloring, $150 \mathrm{ml}$ of dragon fruit peel distillate, $835 \mathrm{ml}$ of aquadest (1000 ml of dye solution) produces the best color. It is thought that there is a residue from the composition of the dragon fruit peel solution which diffuses on the aluminum surface. This is proven empirically. The resulting lighter color on aluminum is due to differences in the composition of the solution mixture [11], [13].

\subsection{Coating Thickness Test Results}

The average thickness of the oxide layer formed on the surface of aluminum 6061 which has been anodized with a variety of purple cabbage coloring solution and dragon fruit peel using Thickness Gun can be seen in table 3.3.

Table. 3.3 Thickness data of anodizing results with purple cabbage dye and dragon fruit peel

\begin{tabular}{|c|c|c|c|c|c|c|c|c|c|}
\hline \multicolumn{10}{|c|}{ Coloring Coating Thicknesses } \\
\hline \multirow{2}{*}{ No } & \multirow{2}{*}{ Coloring Type } & \multirow{2}{*}{ Code } & \multicolumn{6}{|c|}{ Thicknesses } & \multirow{2}{*}{ Average } \\
\hline & & & \multicolumn{3}{|c|}{ Top Surface } & \multicolumn{3}{|c|}{ Bottom Surface } & \\
\hline 1 & \multirow{6}{*}{ Purple Cabbage } & $2 \mathrm{u}$ & 22.500 & 6.100 & 7.400 & 27.500 & 8.600 & 23.800 & 15.983 \\
\hline 2 & & $3 \mathrm{u}$ & 11.100 & 8.600 & 35.500 & 20.000 & 17.500 & 32.700 & 20.900 \\
\hline 3 & & $5 u$ & 9.900 & 21.300 & 8.600 & 34.200 & 16.200 & 13.600 & 17.300 \\
\hline 4 & & $6 u$ & 6.100 & 11.100 & 46.000 & 17.500 & 4.900 & 23.800 & 18.233 \\
\hline 5 & & $7 u$ & 13.600 & 17.500 & 22.600 & 11.100 & 8.600 & 37.100 & 18.417 \\
\hline 6 & & $8 u$ & 9.900 & 7.400 & 16.200 & 18.800 & 6.100 & 12.300 & 11.783 \\
\hline 7 & \multirow{6}{*}{ Dragon Fruit Peel } & 3 & 8.600 & 16.200 & 22.600 & 4.900 & 13.600 & 14.900 & 13.467 \\
\hline 8 & & 5 & 3.600 & 4.900 & 9.800 & 8.600 & 11.100 & 14.900 & 8.817 \\
\hline 9 & & 6 & 11.100 & 13.600 & 12.300 & 8.600 & 16.200 & 23.800 & 14.267 \\
\hline 10 & & 7 & 17.500 & 20.000 & 14.900 & 12.300 & 16.200 & 21.300 & 17.033 \\
\hline 11 & & 8 & 16.200 & 21.300 & 14.900 & 18.800 & 17.500 & 23.800 & 18.750 \\
\hline 12 & & 9 & 12.300 & 11.100 & 13.600 & 14.900 & 7.400 & 22.500 & 13.633 \\
\hline
\end{tabular}




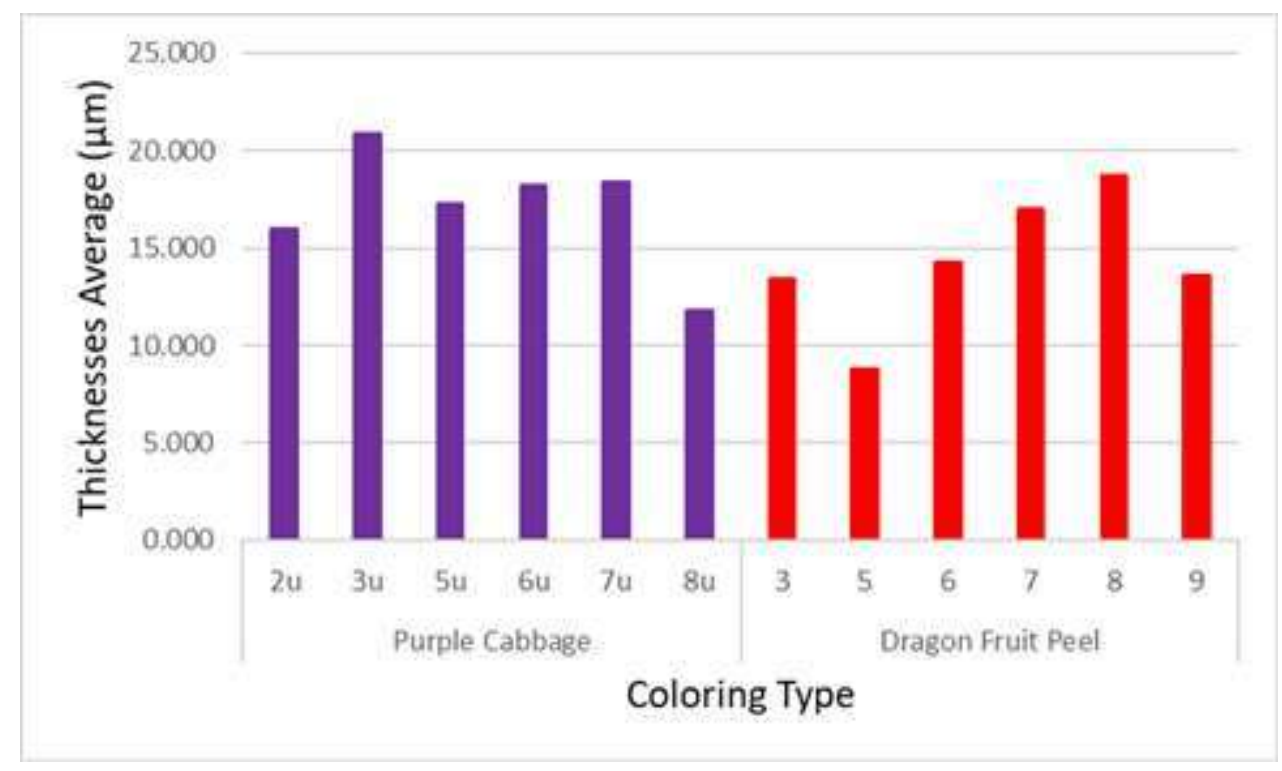

Figure 3.3. Graph of Thickness Value of the coloring layer with variations of the purple cabbage and dragon fruit peel dye solution

Figure 3.3 shows that the highest layer thickness is the result of anodizing using a purple cabbage dye solution, namely in the $2 \mathrm{u} 1$ specimen with $30 \mathrm{ml}$ of purple food coloring, $100 \mathrm{ml}$ of purple cabbage distillate, $870 \mathrm{ml}$ of aquadest (1000 ml of dye solution) with a thickness value of $29.550 \mu \mathrm{m}$ but the color the resulting less evenly. While the highest layer thickness resulted from anodizing using dragon fruit peel dye solution, namely specimen 8 with $45 \mathrm{ml}$ red food coloring, $150 \mathrm{ml}$ dragon fruit peel distillate, $805 \mathrm{ml}$ aquadest (1000 ml dye solution) with a thickness value of $18,750 \mu \mathrm{m}$. The variation in the concentration of the dye solution does not affect the thickness of the resulting oxide layer. The oxide layer and pore size are influenced by temperature, electric current, voltage, solution concentration, and immersion time in the electrolyte solution during the anodizing process. So the factors that greatly affect the quality of the dye solution diffusion are the correct pore size and thickness of the oxide layer so that the dye can adhere perfectly to the surface of the specimen [15], [16].

\subsection{Micro Structure Testing Results}

Microstructure testing was carried out on the surface of the stained specimens with purple cabbage and anodized dragon fruit peel using a Nikon optical microscope with a 200x magnification. The data from the microstructure observations on the 6061 aluminum surface that had been anodized with a variety of purple cabbage dye and dragon fruit peel using a Nikon optical microscope with a magnification of $200 \mathrm{x}$ can be seen in table 3.4 . 
International Journal of Advances in Scientific Research and Engineering (ijasre), Vol 7 (2), February -2021

Table 3.4. Anodizing 200x micro-test results with purple cabbage

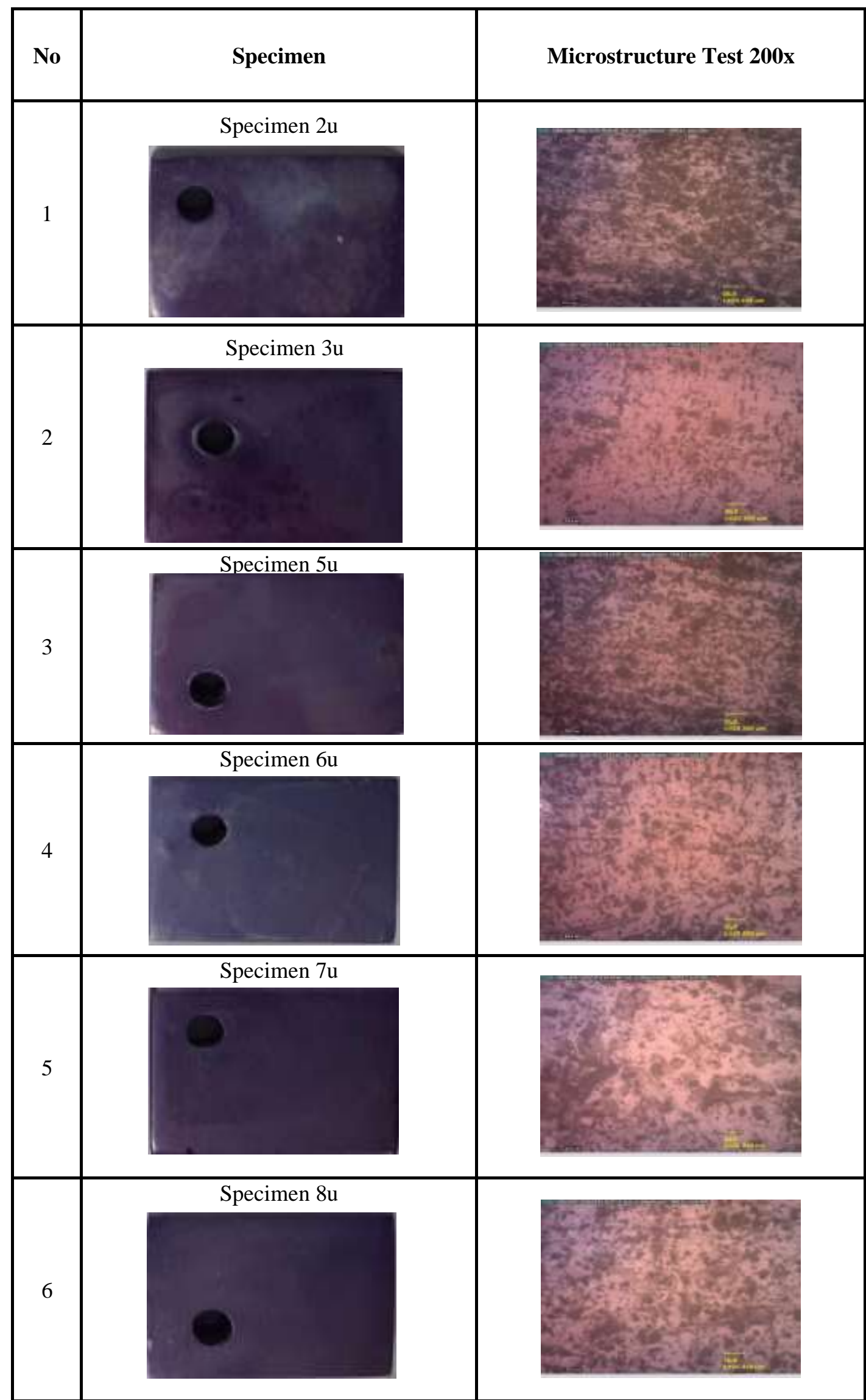


International Journal of Advances in Scientific Research and Engineering (ijasre), Vol 7 (2), February -2021

Table 3.5. Anodizing 200x micro-test results with dragon fruit peel

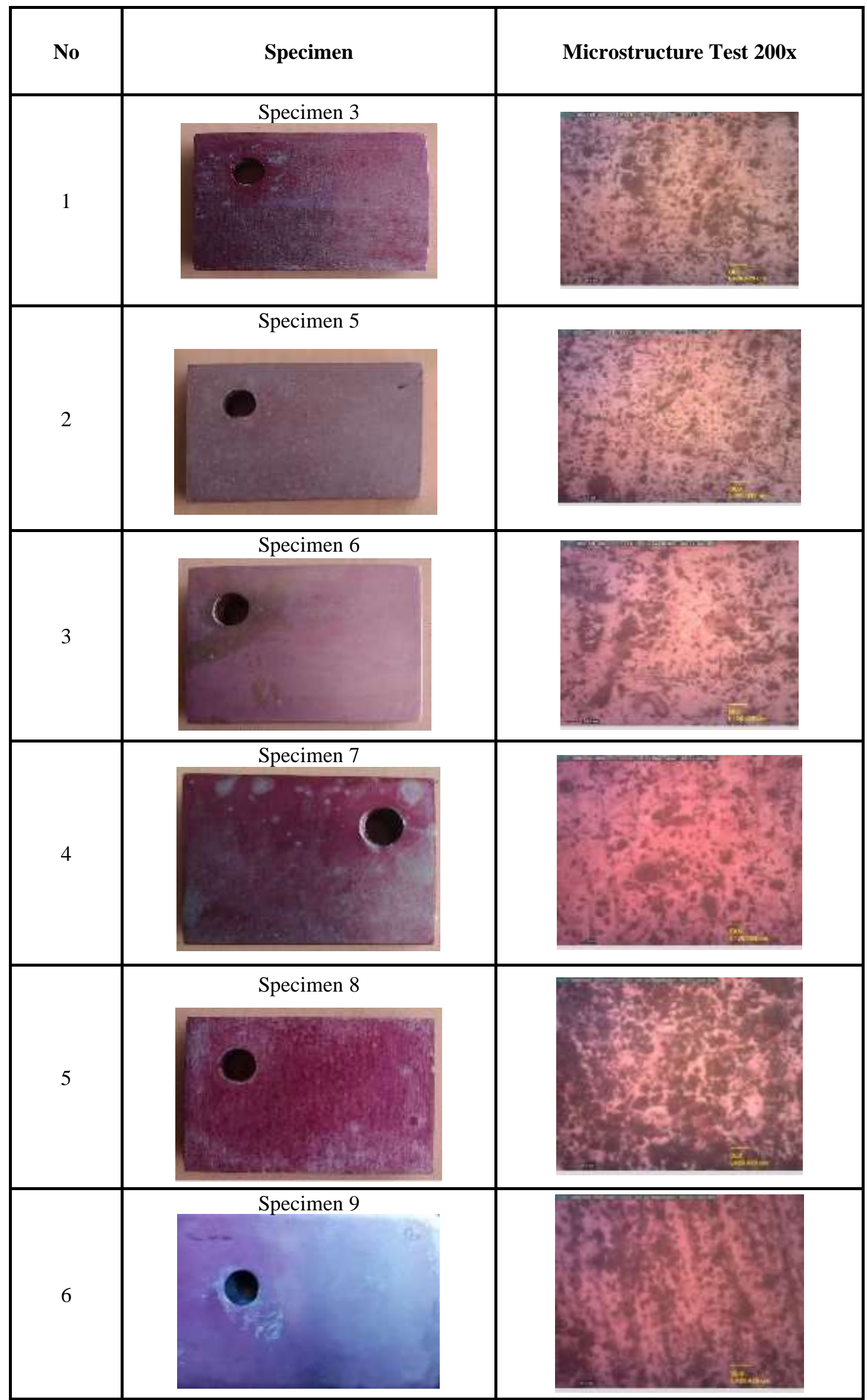


Table 3.4 shows that there is a correlation between\% pores and color brightness. The more uniform the pores and the greater the $\%$, the higher the absorption of the specimen for the dye and the lighter the color. In the $6 \mathrm{u}$ anodizing specimen using purple cabbage dye with a composition of $15 \mathrm{ml}$ of purple food coloring, $150 \mathrm{ml}$ of purple cabbage distillate, $835 \mathrm{ml}$ of aquadest (1000 $\mathrm{ml}$ of dye solution) has a homogeneous\% pore, this affects the absorption of the specimen to the dye. Maximum absorption will produce a cyan-blue color that is evenly distributed on the specimen surface. According to table 3.5 shows the 6 anodizing specimens using dragon fruit peel dye with a composition of $15 \mathrm{ml}$ red food coloring, $150 \mathrm{ml}$ dragon fruit peel distillate, $835 \mathrm{ml}$ aquadest (1000 $\mathrm{ml}$ dye solution) also has a homogeneous pore\%, this has an effect on absorption specimens against dyes. The maximum absorption will produce a red-orange color that is evenly distributed on the specimen surface [15], [17].

\subsection{Micro Vickers Hardness Testing Results}

The specimens were tested for hardness on the surface using the micro Vickers hardness test.

Table 3.6. The results of the hardness test used purple cabbage

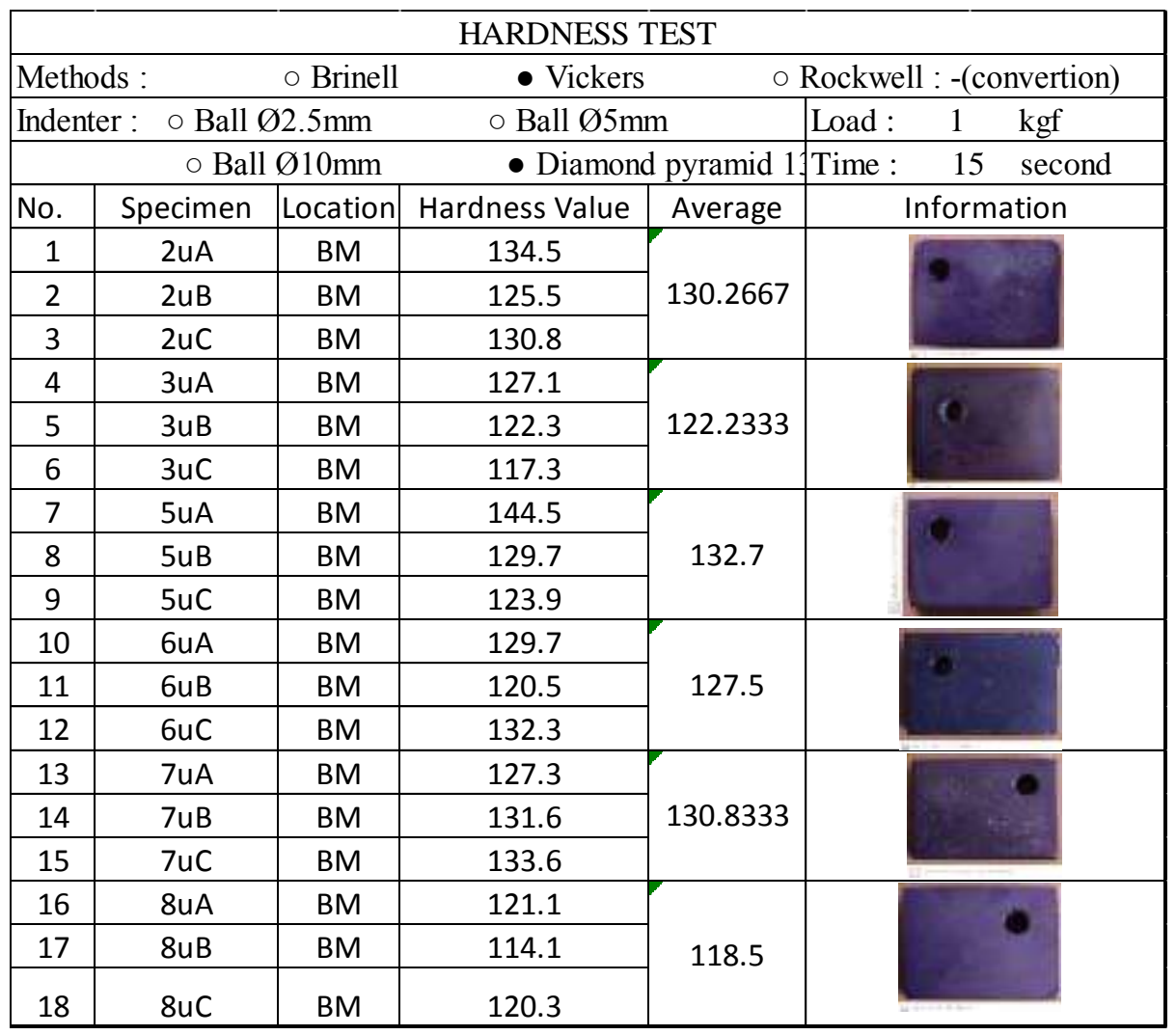

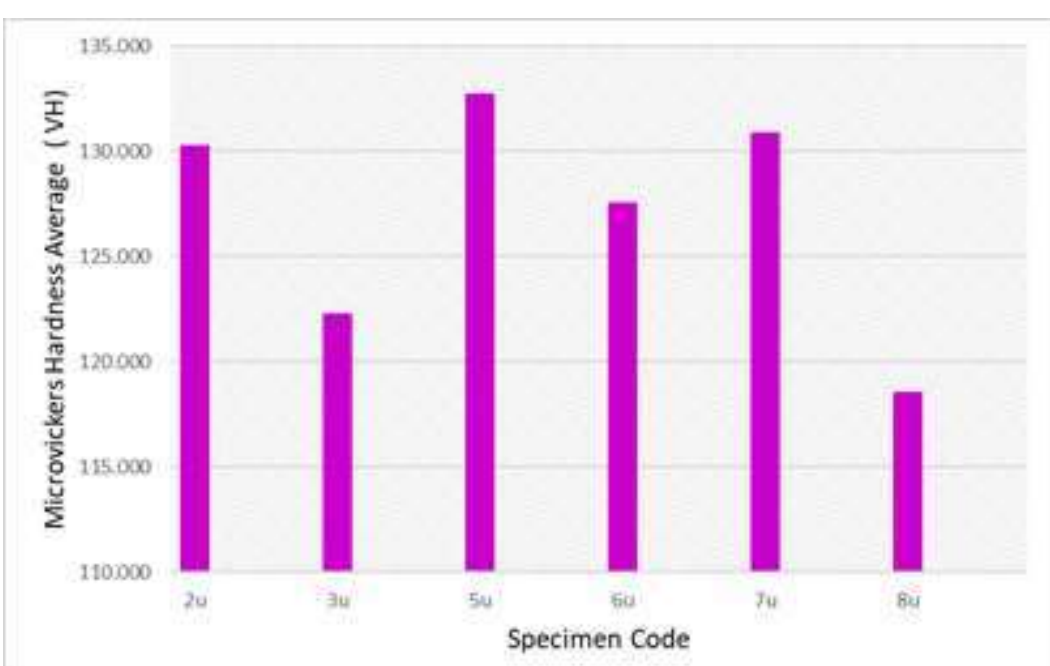

Figure 3.4. Micro Vickers Hardness Value of staining coating 
International Journal of Advances in Scientific Research and Engineering (ijasre), Vol 7 (2), February -2021

Table 3.7 Hardness test results using dragon fruit peel

\begin{tabular}{|c|c|c|c|c|c|}
\hline \multicolumn{6}{|c|}{ HARDNESS TEST } \\
\hline Methods: & \multicolumn{2}{|c|}{ o Brinell } & \multicolumn{2}{|l|}{ - Vickers } & Rockwell : -(convertion \\
\hline Indenter : & \multicolumn{2}{|c|}{$\circ$ Ball Ø2.5mm } & \multicolumn{2}{|c|}{$\circ$ Ball Ø5mm } & Load : $\quad 1 \quad$ kgf \\
\hline \multicolumn{3}{|c|}{$\circ$ Ball Ø10mm } & \multicolumn{2}{|c|}{ - Diamond pyramid } & 15 second \\
\hline No. & Specimen & Location & $\begin{array}{c}\text { Hardness } \\
\text { Value }\end{array}$ & Average & Information \\
\hline 1 & $3 \mathrm{~A}$ & $\mathrm{BM}$ & 120.2 & \multirow{3}{*}{140.2667} & \\
\hline 2 & $3 B$ & $\mathrm{BM}$ & 150.8 & & \\
\hline 3 & $3 C$ & $\mathrm{BM}$ & 149.8 & & \\
\hline 4 & $4 \mathrm{~A}$ & $\mathrm{BM}$ & 137.8 & \multirow{3}{*}{132.5} & \multirow{3}{*}{ - } \\
\hline 5 & $4 \mathrm{~B}$ & $\mathrm{BM}$ & 127.4 & & \\
\hline 6 & $4 C$ & $\mathrm{BM}$ & 132.3 & & \\
\hline 7 & $5 \mathrm{~A}$ & $\mathrm{BM}$ & 122.9 & \multirow{3}{*}{132.7667} & \multirow{3}{*}{ e } \\
\hline 8 & $5 B$ & $\mathrm{BM}$ & 135.7 & & \\
\hline 9 & $5 C$ & $\mathrm{BM}$ & 139.7 & & \\
\hline 10 & $6 \mathrm{~A}$ & $\mathrm{BM}$ & 136.4 & \multirow{3}{*}{132.1333} & \\
\hline 11 & $6 \mathrm{~B}$ & $\mathrm{BM}$ & 133.1 & & \\
\hline 12 & $6 C$ & $\mathrm{BM}$ & 126.9 & & \\
\hline 13 & $7 \mathrm{~A}$ & $\mathrm{BM}$ & 139.6 & \multirow{3}{*}{136.3333} & \\
\hline 14 & $7 B$ & $\mathrm{BM}$ & 130.3 & & \\
\hline 15 & $7 C$ & $\mathrm{BM}$ & 139.1 & & \\
\hline 16 & $8 \mathrm{~A}$ & $\mathrm{BM}$ & 159.4 & \multirow{3}{*}{159.4667} & \\
\hline 17 & $8 B$ & $\mathrm{BM}$ & 162.6 & & \\
\hline 18 & $8 \mathrm{C}$ & $\mathrm{BM}$ & 156.4 & & \\
\hline
\end{tabular}

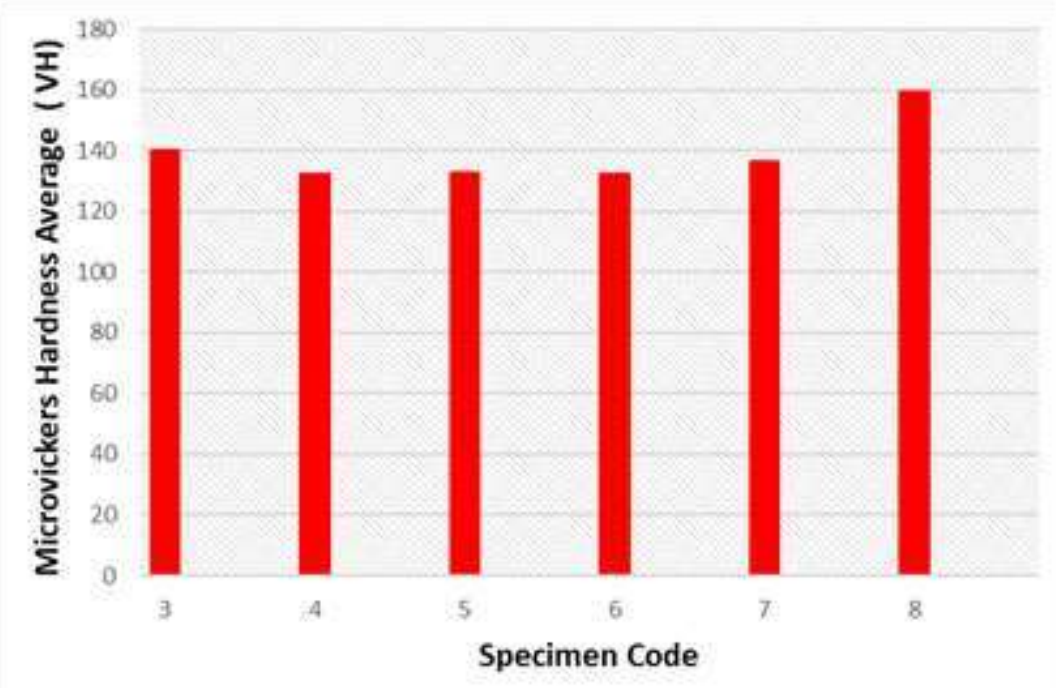

Figure 5. Thickness value of the coloring layer

Figure 5 shows that the highest anodizing hardness test uses a purple cabbage dye solution, namely the $5 \mathrm{u}$ specimen with $45 \mathrm{ml}$ of purple food coloring, $120 \mathrm{ml}$ of purple cabbage distillate, $835 \mathrm{ml}$ of aquadest ( $1000 \mathrm{ml}$ of dye solution) with an average hardness value of $132.700 \mathrm{HV}$. however, the resulting color is not evenly distributed. While the highest layer thickness resulted from anodizing using dragon fruit peel dye solution, namely specimen 8 with $45 \mathrm{ml}$ of red food coloring, $150 \mathrm{ml}$ of dragon fruit peel distillate, $805 \mathrm{ml}$ of aquadest (1000 $\mathrm{ml}$ of dye solution) with an average hardness value of $159.467 \mathrm{HV}$. The variation in the concentration of the dye solution does not affect the hardness of the resulting oxide layer. The oxide layer and pore size are influenced by temperature, electric current, voltage, solution concentration, and immersion time in the electrolyte solution during the anodizing process. Thus, the factors that greatly influence the diffusion quality of the dye solution are the correct pore size and thickness of the oxide layer, then the dye can adhere perfectly to the surface of the specimen [13], [17]. 


\section{CONCLUSION}

According to the results and discussion of the research, it could be concluded as follows:

1. The highest color brightness (RGB) was anodizing using purple cabbage dye, namely in the $6 \mathrm{u}$ specimen with $53.08397 \%$ dominated by cyan - blue colors with $\mathrm{R} 73 \%$, G 74\%, B 95\%, thus, a composition of $15 \mathrm{ml}$ of food coloring purple, $150 \mathrm{ml}$ of purple cabbage distillate, $835 \mathrm{ml}$ of aquadest (1000 $\mathrm{ml}$ of dye solution) produces the best colors. It is thought that there is a residue from the composition of the purple cabbage solution which diffuses on the aluminum surface.

2. The highest brightness of the color (RGB) was anodizing using purple cabbage dye, namely at the highest brightness in specimen 6 with $27.7353 \%$ dominated by Red - Orange with R 156\%, G 92\%, B 119\%, and indeed the colors produced more by the color of the dragon fruit peel than the other specimens. Thus, a composition of $15 \mathrm{ml}$ of red food coloring, $150 \mathrm{ml}$ of dragon fruit peel distillate, $835 \mathrm{ml}$ of aquadest $(1000 \mathrm{ml}$ of dye solution) produces the best color. It is thought that there is a residue from the composition of the dragon fruit peel solution which diffuses on the aluminum surface.

3. The highest layer thickness was the result of anodizing using a purple cabbage dye solution, namely in $2 \mathrm{u} 1$ specimens with 30 $\mathrm{ml}$ of purple food coloring, $100 \mathrm{ml}$ of purple cabbage distillate, $870 \mathrm{ml}$ of aquadest (1000 $\mathrm{ml}$ of dye solution) with a thicknes $\mathrm{s}$ value of $29.550 \mu \mathrm{m}$ but the resulting color was uneven.

4. The highest layer thickness resulted from anodizing using dragon fruit peel dye solution, namely specimen 8 with $45 \mathrm{ml}$ of red food coloring, $150 \mathrm{ml}$ of dragon fruit peel distillate, $805 \mathrm{ml}$ of aquadest (1000 $\mathrm{ml}$ of dye solution) with a thickness value of $18,750 \mu \mathrm{m}$.

5. The highest anodizing hardness test used a purple cabbage dye solution, namely the $5 \mathrm{u}$ specimen with $45 \mathrm{ml}$ of purple food coloring, $120 \mathrm{ml}$ of purple cabbage distillate, $835 \mathrm{ml}$ of aquadest (1000 ml of dye solution) with an average hardness value of 132.700 HV but the resulting color was less equally.

6. The highest hardness test resulted from anodizing using dragon fruit peel dye solution was specimen 8 with $45 \mathrm{ml}$ of red food coloring, $150 \mathrm{ml}$ of dragon fruit peel distillate, $805 \mathrm{ml}$ of aquadest (1000 ml of dye solution) with an average hardness value of 159.467 HV.

7. The more uniform the pores and the greater the $\%$, the higher the absorption of the specimen for the dye and the lighter the color. In the $6 \mathrm{u}$ anodizing specimen using purple cabbage dye with a composition of $15 \mathrm{ml}$ of purple food coloring, $150 \mathrm{ml}$ of purple cabbage distillate, $835 \mathrm{ml}$ of aquadest (1000 $\mathrm{ml}$ of dye solution) has a homogeneous\% pore, this affects the absorption of the specimen on purple cabbage dye. Maximum absorption will produce a cyan-blue color that is evenly distributed on the specimen surface.

8. In the anodizing specimen 6 using dragon fruit peel dye with a composition of $15 \mathrm{ml}$ red food coloring, $150 \mathrm{ml}$ dragon fruit peel distillate, $835 \mathrm{ml}$ aquadest (1000 $\mathrm{ml}$ dye solution) also has a homogeneous\% pore, this affects the absorption of the specimen on peel dye. Dragon fruit. The maximum absorption will produce a red-orange color that is evenly distributed on the specimen surface.

9. The variation in the concentration of the dye solution does not affect the thickness of the resulting oxide layer. The oxide layer and pore size are influenced by temperature, electric current, voltage, solution concentration, and immersion time in the electrolyte solution during the anodizing process. So the factors that greatly influence the diffusion quality of the dye solution are the correct pore size and thickness of the oxide layer so that the dye can adhere perfectly to the surface of the specimen.

\section{ACKNOWLEDGMENT}

The author would like to thank LPPM of the University of Merdeka Malang, the Foundation of Malang Merdeka College, and the University of Merdeka Malang, in particular for providing funding for Internal Innovation research 2020.

\section{REFERENCES}

[1] “ALUMINUM 6061,” Alloy Dig., 1973, doi: 10.31399/asm.ad.al0205.

[2] Matweb, “Aluminum 6061-T6; 6061-T651,” MatWeb, 2015.

[3] S. A. Salman and M. Okido, "Anodization of magnesium (Mg) alloys to improve corrosion resistance," in Corrosion Prevention of Magnesium Alloys: A volume in Woodhead Publishing Series in Metals and Surface Engineering, 2013. 
International Journal of Advances in Scientific Research and Engineering (ijasre), Vol 7 (2), February -2021

[4] C. J. Donahue and J. A. Exline, “Anodizing and coloring aluminum alloys,” J. Chem. Educ., 2014, doi: $10.1021 /$ ed3005598.

[5] M. Nozari Nezhad, A. Kolahi, M. KazemZad, and M. Saiedifar, "Electrolytic coloring of anodized aluminum by copper," 2014, doi: 10.4028/www.scientific.net/AMR.829.381.

[6] M. V. Diamanti, B. Del Curto, V. Masconale, C. Passaro, and M. P. Pedeferri, "Anodic coloring of titanium and its alloy for jewels production," Color Res. Appl., 2012, doi: 10.1002/col.20683.

[7] T. Pujilestari, "Review: Sumber dan Pemanfaatan Zat Warna Alam untuk Keperluan Industri," Din. Kerajinan dan Batik Maj. Ilm., 2016, doi: 10.22322/dkb.v32i2.1365.

[8] R. Putri, T. L. Wargasetia, and S. Tjahjani, "Efek Larvasida Ekstrak Etanol Daun Pandan Wangi (Pandanus amaryllifolius Roxb.) terhadap Larva Nyamuk Culex sp,” Glob. Med. Heal. Commun., 2017, doi: 10.29313/gmhc.v5i2.2117.

[9] I. Yunus and T. Sarungu, "Pemanfaatan Ekstrah Kulit Buah Manggis Sebagai Pewarna Logam Aluminium,” Ind. Res. Work. Natl. Semin., 2012.

[10] A. Suprapto and A. Suyatno, "PENGARUH VARIASI KOMPOSISI DEGREASING DAN WAKTU ANODIZING,” vol. 2, pp. 893-902, 2013.

[11] I. Nitya Santhiarsa, "Pengaruh Kuat Arus Listrik Dan Waktu Proses Anodizing Dekoratif Pada Aluminium Terhadap Kecerahan Dan Ketebalan Lapisan,” J. Energi Dan Manufaktur, 2010.

[12] C. H. Huang, Y. W. Chen, and C. M. Chen, "Chromatic Titanium Photoanode for Dye-Sensitized Solar Cells under Rear Illumination,” ACS Appl. Mater. Interfaces, 2018, doi: 10.1021/acsami.7b18351.

[13] F. Nugroho et al., "Pengaruh Variasi Larutan Elektrolit Terhadap Warna," Angkasa J. Ilm. Bid. Teknol., 2013.

[14] S. U. Ofoegbu, F. A. O. Fernandes, and A. B. Pereira, "The sealing step in aluminum anodizing: A focus on sustainable strategies for enhancing both energy efficiency and corrosion resistance," Coatings, 2020, doi: $10.3390 /$ coatings 10030226 .

[15] A. Suprapto, P. Setyawan, A. Setiawan, and D. Tsamroh, "the Effect of Anodizing Solution Type Against the Coating Thickness and Wear Rate of Aluminum 6061,” vol. 10, no. 12, pp. 57-64, 2019.

[16] M. Taufiqurrahman, M. Toifur, I. Ishafit, and A. Khusnani, "Investigation on Effect of Solution Temperature on The Structure of $\mathrm{Cu} / \mathrm{Ni}$ Layer in The Electroplating Assisted withParallel Magnetic Field," J. Aceh Phys. Soc., 2020, doi: 10.24815/jacps.v9i3.16351.

[17] A. Suprapto, P. E. Setyawan, and D. I. Tsamroh, "INVESTIGATION OF COATING THICKNESS , HARDNESS AND WEAR RESISTANCE OF ALUMINUM 6061 BY ANODIZING TREATMENT,” vol. 11, no. 10, pp. 1-12, 2020. 